\title{
Wine Index of Salubrity and Health (WISH): an evidence-based instrument to evaluate the impact of good wine on well-being
}

This article was published in the following Dove Press journal:

International Journal of Wine Research

\author{
Andrea Rossi ${ }^{1}$ \\ Ferdinando Fusco ${ }^{2}$ \\ 'Sommelier AIS (Associazione Italiana \\ Sommelier), Florence, Italy; ${ }^{2}$ Urologic \\ Clinic, University Federico II Of Naples, \\ Naples, Italy
}

\begin{abstract}
Wine, as any other alcoholic drink, should be consumed in moderate dosages. The scientific literature reports a huge number of articles describing the various health benefits of moderate wine drinking, but none have so far summarized the different types of evidence supporting these effects. Furthermore, there is no proof that any specific wine might be more or less beneficial than any other according to its content of specific nutrients and components. The aim of this article was to identify the individual components of wine that are known to have a potential to effect on health, in order to create a wine-specific index to grossly estimate the impact of moderate wine drinking on well-being. A deep search was performed on the medical literature to choose those articles that could explain the role of the main components of wine on health. The proper dosages and the instruments to evaluate the quality of wines were identified and are described herein. Evidence supporting the role of alcohol, acidity, sulfur dioxide, malic acid, metals, polyphenols, and other components of wine on health was identified and summarized, and the various links with health benefits are described. Then a Wine Index of Salubrity and Health (WISH) was developed which, as a rapidly available and effective instrument, will help to understand at a glance the potential beneficial effect of a specific wine.
\end{abstract}

Keywords: wine, health, alcohol, polyphenols, sulfur dioxide, metal, wine quality

\section{Introduction}

Wine differs from other alcoholic drinks as it is associated with relaxation, reflection, conviviality, celebration, and a certain amount of dry humor. ${ }^{1}$ It is used differently in various cultures to celebrate a special occasion, enhance a fine meal, or be an integral part of the daily diet.

Wine has been used for medical purposes at least since $2200 \mathrm{BCE}^{2}$ and there is now growing evidence that correct doses of wine can be beneficial to human health. ${ }^{3}$ People who regularly drink wine with food have been reported to have better self-reported health, ${ }^{4,5}$ higher self-esteem, and less psychological distress than others. ${ }^{6}$ Some medical studies have revealed certain health benefits of drinking the "right" dose of wine, which in certain cases may be more beneficial than not drinking wine or other alcoholic beverages. For instance, serum uric acid levels did not increase with increasing wine intake but grew with beer or liquor higher intake. Light-to-moderate wine consumption provides several beneficial effects on the skeletal system, as reduced risk of fractures and bone mass loss, ${ }^{8}$ and also better women's sexual health. ${ }^{9}$ Furthermore, wine consumers have a $25-35 \%$ lower risk
Correspondence: Andrea Rossi Sommelier AIS (Associazione Italiana Sommelier), via U. Saba, 5, 50I35

Florence, Italy

Tel +393519151347

Email molezzano.I@libero.it 
of cardiovascular disease compared to consumers of beer and spirits. ${ }^{10}$ Interestingly, alcohol consumption up to 24 g/day does not increase the mortality risk for accidents. $^{11}$

Similar findings had been published when the so called "Mediterranean diet" was delineated in the small village of Pioppi in Southern Italy. ${ }^{12}$ The Mediterranean diet also involves a "Mediterranean way of drinking", meaning regular, moderate consumption of wine, mainly with food. This drinking attitude is believed to increase longevity reducing the risk of cardiovascular disease but not appreciably influencing the overall risk of cancer. ${ }^{13}$ Drinking wine reduces the risk of cardiovascular disease and metabolic syndrome, is linked with a remarkable decrease of abdominal circumference, an increase in blood serum high-density lipoprotein (HDL), ${ }^{14,15}$ a reduction in blood triglycerides, a decrease of blood pressure, a lowering in glycaemia, ${ }^{16,17}$ and a reduction in mortality by $25-35 \% .^{18-20}$

Other studies have investigated the so-called "French paradox". This finding concerns wine and health and shows that the French consuming rich, high-fat foods have a lower incidence of coronary disease when compared to other countries having similar dietary habits, such as Scotland. ${ }^{21}$ The authors of this first study concluded that this apparent paradox was "likely due to inhibition of platelet aggregation by regular, moderate ethanol consumption in the form of wine". Further studies have shown that the polyphenols (PPs) in wine could explain the beneficial effect of wine on preventing several diseases. ${ }^{18,22,23}$ The subsequent media exposure of the French paradox has driven the continuous increase of research on the influence of wine on health ${ }^{24}$ and also the increasing consumption of wine worldwide since the early 1990s. ${ }^{25}$

Reduced risk of heart disease or stroke is said to be linked with drinking a glass of wine occasionally. ${ }^{26}$ Moderate wine consumption has a beneficial effect on atherothrombotic events as coronary heart disease, ${ }^{26}$ ischemic stroke, ${ }^{27}$ peripheral arterial disease and congestive heart failure, ${ }^{28}$ and can reduce the risk of death by cardiovascular disease, stroke, and cancer. ${ }^{29}$

Some components of wine have been shown to push up the immune system, inhibit cancer, and provide protection against cardiovascular diseases, diabetes and Alzheimer's Disease (AD). These authors conclude that regular wine consumption, in the correct dose, can increase life duration. ${ }^{29-31}$ This observation has been confirmed in another 29-yearlong study where red wine drinkers had a one third lower mortality rate than beer or vodka drinkers, ${ }^{32}$ while another study concluded that men who consumed wine had a life expectancy of about 5 years longer than those who did not consume alcoholic beverages. ${ }^{31}$

Furthermore, daily consumption of a glass of wine can have an antidepressant effect, probably linked with an hippocampal neuroprotective effect. ${ }^{32}$ Other studies have confirmed that moderate wine consumption is linked with the reduction of dementia, AD and depression, while intense drinking is associated with an increased risk of stroke and depression. ${ }^{33,34}$ The moderate consumption of wine increases its positive effects when associated with a healthy diet and lifestyle, such as the Mediterranean diet, where wine is synergic with other foods like olive oil, fruits, cereals, vegetables, milk, and cheese. ${ }^{19,35}$

There are several explanations for the beneficial effects of wine as there are thousands of studies exploring the possible reasons behind them. ${ }^{1}$

Even if most moderate drinkers are more interested in wine's sensory pleasures and relaxing effect rather than its health benefit, ${ }^{36}$ this growing evidence qualifies wine to be included in the official pharmacopeia as confirmation of its pharmacologic characteristics. ${ }^{37}$ Good quality, genuine wines produced with selected healthy grapes belonging to organic, fertile territories without the addition of synthetic additives and bottled by grape cultivators are considered the healthiest because wine cannot be classified as only a pharmaceutical specialty but is, as well, a truly pleasant libation while having a recognizable organoleptic appeal. $^{37}$

The objective of this paper is to conceptually review the available literature on the beneficial effects of wine and to introduce the creation of an index linking the chemical composition of wine with its impact on health.

\section{Methods}

A comprehensive literature search was performed on Pubmed and Google Scholar in June 2017 to identify any possible scientific evidence supporting a link between wine and health improvement. The keyword used for both searches was "wine health benefits". Only articles in English, Spanish or Italian were selected when any quantitative relation between wine consumption and any effect on health was described. Retrieved references were checked by the authors independently. Any information on the relation between wine consumption, and one or more-than-one compound of wine, and heath benefit was 
selected from retrieved articles in a non-systematic manner, after author's agreement.

Wine is mainly composed of water (80-90\%), alcohol (ethyl 8.0-15.0\%, methyl, 2,3-butylene glycol, acetoin 0.3$0.19 \%$ ), carbohydrates (glucose $0.05-0.1 \%$, fructose 0.05 $0.1 \%$, pentoses $0.08-0.2 \%)$, inositol $(0.03-0.05 \%)$, fucose $(0.0005 \%)$, glycerol $(0.3-1.4 \%)$, aldehyde $(0.001-0.05 \%)$, tartaric, malic, lactic, succinic, acetic, galacturonic, p-hydroxyglutaric, amino, citric, fumaric, oxalic, $\alpha$-oxoglutaric, aconitic, malonic, malic, pyrorocemic, pantothenic acids (0.3-1.1), nitrogenous (0.01-0.09\%) and mineral compounds including potassium, magnesium, aluminum, manganese, chloride, fluoride, carbon dioxide, phosphate, sulfate, calcium, iodine, silicic acid, sodium, iron, boron, copper, rubidium, oxygen $(0.15-0.4 \%)$ and traces of arabinose, rhamnose and xylose. ${ }^{18}$

We selected those articles reporting on a clinical relation between the specific chemical components of wine (total alcohol, reducing sugars, net dry extract, total dry extract, non-reducing extract, relative density $\left[20^{\circ} \mathrm{C}\right]$, total acidity, net volatile acidity, net hydrogen sulphide, total hydrogen sulphyde $\left(\mathrm{SO}_{2}\right), \mathrm{pH}$, malic acid, copper, color intensity, color tone, total PPs, anthocyanins $[\mathrm{Acs}]^{38}$ ) and health. The relative weight each chemical entity has on health was calculated based upon a recommended daily consumption of wine as identified from articles retrieved. Furthermore, we tried to assess the link between beneficial effects of wine and its quality level.

\section{Results}

\section{Total alcohol}

Wine contains $8-15 \%$ ethanol by weight. The association between ethanol intake and chronic disease such as diabetes, cardiovascular disease, and cancer have not been fully established. ${ }^{18}$ Ethanol is absorbed very quickly into the stomach and the intestine and traces can be found in the blood 5 mins after consumption, whilst the entire quantity of alcohol ingested is completely absorbed within 40 mins. When the alcohol level of drivers reaches $1.5 \mathrm{mg} / \mathrm{L}$ the risk of a fatal road accident is increased 25-fold. Wine's effects on psychological and motor functions include a slowing down of reaction time and coordination, an alteration in the ability to selfdetermine speed, distance and position, an alteration of the ability to follow a precise path or deal with an unexpected event, an alteration of sight, with a reduction in the field of vision and a prolongation of adjustment time for eyes blinded by lights and more aggressive reactions and/or less compliance than usual. $^{13}$
To give a better awareness on excessive alcohol consumption, a wide concordance exists to add the total content of alcohol in all alcoholic beverages labels to the percentage, that is already mandatory. ${ }^{39}$ Alcohol is a nutrient giving $7 \mathrm{Kcal} / \mathrm{g}$ calories upon intake, being an intermediate between carbohydrates and lipids.

The known potential protective effects of alcohol against coronary heart disease and stroke include reduced levels of C-reactive protein, increased levels of HDL and apolipoprotein (Apo) A, increased thromboxane-prostacyclin ratio and release of plasminogen activator, decreased levels of fibrinogen and platelet aggregation and additive effects with aspirin, enhanced insulin sensitivity and decreased blood insulin levels. ${ }^{40-42}$ The influence of alcohol on the benignant effects of moderate wine drinking is still under debate in the scientific community mainly because high blood concentrations of ethanol induce oxidation and inflammation that might be linked with liver damage, mucosal lesions, and other serious events. Moderate ethanol intake, from any type of beverage, improves lipoprotein metabolism ${ }^{18}$ and lowers the risk of fatal and non-fatal cardiovascular disease, coronary heart disease, and all-cause mortality ${ }^{43,44}$ when compared to nonconsumption, former consumption, occasional consumption and heavy consumption. ${ }^{45}$ These results seem to be independent of age, sex, Body Mass Index (BMI), systolic blood pressure, use of anti-hypertensive drugs or statins, diabetes mellitus, high density lipoprotein cholesterol, and whether the patient had received dietary advice. ${ }^{45}$ Moderate wine consumption is associated with a better objective and perceived health status, less vascular inflammation, and lower prevalence of depression but has no clinically relevant effect on 4 year clinical outcome in patients with chronic heart failure. ${ }^{46}$ It reduces the prevalence of metabolic syndrome in an elderly Mediterranean population at high cardiovascular risk $^{47}$ and halves the risk of metabolic syndrome in women compared with non-drinkers. ${ }^{48}$

The ethanol contained in wine improves the absorption of flavonoids (Fvs), ${ }^{49,50}$ increases the degree of HDL cholesterol and reduces aggregation of blood platelets. ${ }^{51}$ In another study, ethanol increased lipo-peroxidation and decreased antioxidants serum parameters; however, some of these changes appear to be thinner when ethanol was consumed as beer or wine. ${ }^{52}$

A systematic review did not find any association between alcohol consumption and serum concentration of interleukin 6 , C-reactive protein (CRP) and tumor necrosis factor- $\alpha{ }^{53}$ Red wine, exclusive of all other alcoholic beverages, decreased CRP, vascular cellular adhesion molecule-1, intercellular 
CAM-1 (ICAM-1), macrophage-1 antigen, very late antigen-4 (VLA-4) and monocyte chemoprotein-1, IL-1a, and VLA-4 lymphocyte expression and lymphocyte function-associated antigen-1, monocyte expression in healthy subjects ${ }^{54}$ and decreased interleukin-6, E-selectin, and ICAM-1 plasma concentrations in high-risk patients. ${ }^{55}$ Furthermore, low to moderate alcohol consumption was associated with reduced atherosclerotic burden in the proximal aortic arch. ${ }^{56}$ Alcohol consumption increases HDL cholesterol in a dose-dependent manner, even in a hypertensive population, ${ }^{57}$ increases ApoAI and does not significantly change triglycerides, total cholesterol, LDL cholesterol or lipoprotein(a). ${ }^{53}$ It decreases plasma ApoB whereas red wine (but not gin) was shown to increase ApoA-I and II in healthy volunteers. ${ }^{54,58}$ Ethanol increases HDL cholesterol as and ApoA-I and II in a high cardiovascular risk population. ${ }^{59}$ Three meta-analyses indicated that moderate alcohol intake can protect against type- 2 diabetes as alcohol improved insulin sensitivity and decreased serum insulin concentrations. $^{22,55,60}$ Even if some authors suggest that moderate alcohol consumption could lower blood pressure, ${ }^{61-63}$ more recent evidence has not confirmed these results. ${ }^{64-66}$ Moderate alcohol consumption is repeatedly associated with blood viscosity, a decreased pro-coagulant state (by lowering several coagulation factors), and enables a higher fibrinolytic capacity. ${ }^{59}$ These results can explain wine's association with a reduced relative risk of stroke in people drinking $<12 \mathrm{mg}$ of alcohol daily. ${ }^{67}$ Finally, moderate alcohol consumption was associated with a reduced incidence of secondary cardiovascular and all-cause mortality. ${ }^{68}$

Alcohol ingestion is likely to be biased ${ }^{69}$ or underestimated $^{70}$ in population surveys on wine consumption, resulting in a possible underestimation of the benefits of moderate wine drinking. Even if the dosage of urinary tartaric acid is suggested to have an objective estimation of wine consumption, ${ }^{71}$ to date no studies exist which assess wine intake with this method.

Moderate consumption of ethanol induces the production of hydroxytyrosol, ${ }^{72}$ a minor metabolite of dopamine and a potent phenolic antioxidant that might be linked with neuroprotective, ${ }^{73}$ DNA-damage protection $^{74}$ and the antioxidant $^{75}$ effects of wine.

The concentration of ethanol in wine seems to slightly affect its health impact when standard daily doses of wine is drunk, whereby lower concentrations seem having a more beneficial effect. The quantity of ethanol providing a maximal health benefit is very low (10-20 g of actual ethanol per day). ${ }^{18}$ We must remember that wine is an alcoholic drink and therefore the risk of high alcohol consumption can well supersede wine's benefits due to moderate and conscious wine drinking ${ }^{33}$ particularly in elders. $^{76}$

\section{The right alcohol dosage}

A daily dose of alcohol above $1 \mathrm{~g} / \mathrm{Kg}$ was established as a health risk by WHO back in 1985. In 1997 the European Committee of WHO indicated that 4 glasses of wine is a standard alcohol daily intake. Other guidelines have been proposed in different countries and for different populations ${ }^{39,77}$ as several attempts to create an algorithm to determine the right dose have been proposed to physicians $^{78}$ but none have been adopted in daily clinical practice. Several campaigns have been conducted in some countries to reduce the risk linked with excessive alcohol consumption, mainly with the aim of alerting people of the risk of alcohol. Even the low risk drinking guidelines highlight these risks but do not advise on the safety of a low dose consumption of alcohol. ${ }^{39}$ As doses and individual absorption vary greatly, mainly in elderly and lighter weight subjects, this dose has to be reduced to 2-3 glasses a day. ${ }^{79}$ One or two glasses of wine per day has been the suggested amount to obtain wine's benefits as reported in recent studies. ${ }^{33}$ The average consumption of alcohol per day not to be exceeded was identified as between 20 and $48 \mathrm{~g}$ /day for men and from 10 to $32 \mathrm{~g} /$ day for women in a multinational European survey. ${ }^{39}$ What was established was that it is important never to drink more than 4 glasses of wine on a single occasion, and that wine should never be consumed by pregnant women, ${ }^{79}$ by people below 18 years of age, when driving, at work or when engaged in any tasks requiring concentration. ${ }^{39}$

A wine glass is typically $200 \mathrm{~mL}$, so a "home measure" of wine in most cases is probably more than enough for daily consumption. ${ }^{13,33}$ The more beneficial dose is linked with gender, age and the subject's physiology or physical state (eg, pregnancy, menopause, etc.) as with genetic factors (for instance Italians, Israelis and Russians seem to have higher tolerant alcohol levels than English, Norwegians, Finnish or Indians), probably because of the different levels and efficiency of the alcohol-dehydrogenase enzyme. ${ }^{79}$ Furthermore, drinking wine while eating delays alcohol absorption, maintaining lower blood concentrations as observed when compared with alcohol ingestion at fasting whereby absorption begins after 5 'and reaches 50\% absorption after $15^{\prime}$. Furthermore, wine consumption with food is linked with wine's cardioprotective effect. ${ }^{80}$ Caffeine slows alcohol absorption, as well as sugar and 
vitamins, while the linoleic acid of olive oil limits the negative effects of high doses of alcohol. Slow drinking delays alcohol absorption as well and increases the pleasure given by tasting a good wine. ${ }^{79}$

The health conditions of the drinker can also highly influence alcohol's tolerability. Alcohol consumption should be reduced, and paralleled with increased water intake, in hot weather. Mixing water and wine is never recommended, while drinking different wines while ingesting the same food does not influence alcohol absorption but, if rightly chosen, enhances food (and wine) intake pleasure. Consumption of any alcoholic beverage should be reduced in subjects with cardiac or hepatic diseases or those ingesting antibiotics, sleep inducers or anticoagulants. Defected wines can cause headaches and sweating. ${ }^{79}$ Furthermore, excessive alcohol drinking is a major public health problem in Europe being responsible for $3.8 \%$ of all deaths and $4.6 \%$ of years of lives lost, affecting families and communities due to violent behavior, abuse, loss of social opportunities, abandonment, an inability to build stable relationships and emotional bonds, disability, and accidents at work and on the road which are typical of alcohol abusers. ${ }^{81}$ Another study concluded that moderate wine drinkers seem to have a reduced risk of becoming heavy or excessive drinkers and that this may add to the explanation of the reported beverage-specific differences in mortality and morbidity. ${ }^{82}$

\section{Net volatile acidity, total acidity, $\mathrm{pH}$}

Volatile acidity refers to the distillable acids present in wine, mainly acetic acid but also lactic, formic, butyric, and propionic acids. Acetic acid is given by the oxidation of ethanol that is mainly performed by acetic acid bacteria. Acetic acid is perceived when having a concentration of $>600 \mathrm{mg} / \mathrm{L}^{83}$ If the concentrations are above $1.2-1.3 \mathrm{~g} / \mathrm{L}$, the taste of wine becomes unpleasant. Too high a concentration is sure to leave a not wanted "vinegar" tasting wine and taints the wine or turns it to vinegar. The levels of volatile acidity increase with time, being more rapid in wines having bacterial contamination. ${ }^{84}$ Thus, the presence of distillable acids cannot be significantly related to the health effects of wine but provide good information on hygiene of the production process.

\section{Sulfur dioxide}

$\mathrm{SO}_{2}$ can be added during the production process to slow oxidation and knock out harmful bacteria. Any wine bottle sold in the US since 1988 and within the EU since 2005 containing more than $10 \mathrm{mg} / \mathrm{L}$ of $\mathrm{SO}_{2}$ is legally required to state "contains sulfites" on their label, meaning that wine contains sodium and potassium sulphides, bisulphides, metabisulphites and calcium bisulphide. ${ }^{85}$ The fermentation process can also naturally produce $\mathrm{SO}_{2}$ at a concentration above the $10 \mathrm{mg} / \mathrm{L} \mathrm{limit}{ }^{86}$ and therefore many "no added sulfite" wines as natural wines, must display "contains sulfites" on the label as well.

Modern wines have a $\mathrm{SO}_{2}$ concentration varying from 20 to $200 \mathrm{mg} / \mathrm{L}$, being well below that observed in dried fruit, which has been dosed at between 500 to $3,000 \mathrm{mg} / \mathrm{L}$ (eg, dried apricots have a $2,000 \mathrm{mg} / \mathrm{kg}$ concentration of sulfites). While this amount could hypothetically cause an adverse reaction in an asthmatic, it would be a very rare occurrence. Reported sulfite intolerance affects less than $1 \%$ of the population. Sulfites do not cause a true allergic reaction, but sulfite-sensitive people may feel some similar responses. Symptoms may develop quickly and can include headaches, a flushed face - rash, red and itchy skin, difficulty in breathing, speaking or swallowing, distress, anxiety, faintness, weakness, eye, lip, face, or throat swelling, cramps, diarrhea and vomiting. ${ }^{87}$

Sulfites are probably not responsible for aftereffects of drinking alcohol either as Andrew Waterhouse, professor of enology at UC Davis, asserts: "There is no medical research data showing that sulfites cause headaches". 88

These legislative rules, together with customer demands, have encouraged the production of "ecological wines," which have recently gained relevant interest. These are produced by environmentally friendly sustainable and integrated production methods. During the production of these wines, a series of strict enological practices are allowed with no additives apart from $\mathrm{SO}_{2}$ possible. The final wine product must have as low an amount of $\mathrm{SO}_{2}$ as possible that must not exceed 70 $100 \mathrm{mg} / \mathrm{L}$, depending on the type of wine. ${ }^{89} \mathrm{SO}_{2}$ concentration should be included in the calculation of the wine health index, being inversely proportional to health effects.

\section{Malic acid}

Malic acid is one of the main contributors of acidity in grapes. Its concentration tends to reduce as grapes ripen, mostly due to metabolic respiration. Malic acid is the fuel in respiration for vine and grape. Malic acid is very important in wine: If there is not enough, the wine tastes "flat," and is more susceptible to spoilage; if there is too much, the wine tastes "green," or "sour." So, the control of the amount of malic acid present in wine is crucial for the winemaker. ${ }^{90}$ One of malic acids' defining characteristics 
is the intensity of its taste, that someone describe as harsh. Because of this, malic acid is replaced with lactic acid through malo-lactic fermentation by some winemakers. Lactic acid is much "softer" than malic acid. ${ }^{90}$

The effects of malic acid present in wine on health is not described in the literature and therefore its concentration does not affect the salubrity index.

\section{Copper}

The presence in wine of some potential harmful compounds such as trace metal compounds, sulfites, phytosanitary products, and some toxics of microbial origin, such as ethyl carbamate, ochratoxin A, and biogenic amines, compromises irreversibly its potential beneficial effect. ${ }^{87}$ Wines contains several metals including aluminum, arsenic, cadmium, chromium, copper, iron, lead, manganese, nickel, and zinc. Most of them can have a negative or positive effect on health, depending on the dosage and source. ${ }^{91}$ Application of fungicides, pesticides, and fertilizers containing cadmium, copper, lead, manganese, and zinc compounds increases the amounts of these metals in wine and strongly affects its healthiness. Arsenic is used as pesticide giving health concerns for producers and drinkers. ${ }^{92}$ The major sources of wine contamination with copper are pesticides as well. ${ }^{91}$ Namely, copper sulfate is used for killing downy mildew. Furthermore, copper is often added to wine as it cuts smelly characteristics associated with organic sulfur compounds that can form during fermentation and bottle aging. The concentration of copper in wine may be lower compared with that in the grape, due to the removal of copper during fermentation. Reduced copper forms insoluble sulfides, which are eliminated through sedimentation together with lees and yeasts. ${ }^{91}$

Human health can be affected by moderate consumption of wines containing high levels of metals, too. Specifically, although metals may be complexed to phenol compounds in wine, at the low gastric $\mathrm{pH}$, free ions of metals can be adsorbed and may cause toxic effects. Their toxicity has been related mainly to interference with other, mostly essential metals and to oxidative stress generation. ${ }^{93,94}$ Some metals such as copper, iron and zinc have nutritional benefits and are needed for a wide range of physiological processes. Despite this, their excessive intake may cause both acute and chronic toxicity. For example, intake of elevated copper in wine can induce nausea, diarrhea, vomiting, and muscle and abdominal pain. Prolonged assumption of elevated copper can harm kidneys and the liver. ${ }^{95}$
The maximum acceptable concentration of copper can vary between 1 and $10 \mathrm{mg} / \mathrm{L} .^{91}$ Thus, copper concentration, even below this lower limit, has been considered as having some impact in WISH calculation, while any concentration linked with pesticide use let the WISH index drop to 0 .

\section{Total polyphenols, anthocyanins, flavonoids}

Wine can be considered an hydro-alcoholic extract rich of PPs. Different from beer and spirits, wine contains several antioxidant polyphenols extracted from the grapes during wine-making which are mainly Fvs and stilbenes belonging to grape tannins and pigments. ${ }^{96}$ A glass of red wine contains 100-200 mg of PPs compared with the 25-50 mg of a white one. Red wine has to be considered a concentrated source of dietary phenolic acids and PPs. ${ }^{97}$

Fvs, including catechins, epi-catechins and pro-cianidyns, anthocyanins (Acs) and flavonols (Fos) as quercetin, and non-flavonoids including benzoic acids, hidroxicinnamics and stilbenes as resveratrol (RST) are the PPs available in wines. Flavan-3-ols, Fos, Acs, and non-flavonoid stilbenes present in red wine are indeed absorbed. ${ }^{79}$ Average concentration of PPs in red and white wines are summarized in Table 1.

Wine Fvs have antioxidant, ${ }^{98}$ atheroprotective ${ }^{99}$ and anti-inflammatory ${ }^{54,100}$ properties both scavenging free radicals and interacting with genes involved in inflammatory processes. ${ }^{79}$ Fvs are present in all wines, but red wines have more than roses or whites. Furthermore, Fvs content may vary between grape varieties and geographical regions. Given the varying PPs content of different wines, we can expect red wines being more beneficial in reducing the risk of stroke. There are even tips that some of the useful effects of wine, including decreased vascular endothelin-1 synthesis $^{101}$ and higher endothelial nitric oxide synthase, ${ }^{102}$ are specific to red wine. Red wine may have specific anti-proliferative and anti-inflammatory effects which are advantageous in preventing atherosclerosis; geographical origin and grape variety may play important roles. ${ }^{42}$ A study from the University of California measured the antioxidants levels of several red wines. Generally speaking, the results of the study highlight that the sweeter the wine, the fewer the Fvs. Petit Syrah, Cabernet Sauvignon, and Pinot Noir seem to have the higher antioxidant effect. Merlots and Red Zinfandels still have some benefits, resulting less potent than the 
Table I Phenolic acid and polyphenol components of red and white wines concentration (mg/L) ${ }^{\mathrm{a}}$

\begin{tabular}{|c|c|c|}
\hline Component & Red wine & White wine \\
\hline Nonflavonoids & $240-500$ & $160-260$ \\
\hline Hydroxybenzoic acids & $0-260$ & $0-100$ \\
\hline P-Hydroxybenzoic acid & 20 & - \\
\hline Gallic acid & $116(26-320)$ & 1.4 \\
\hline Total gallates & $40(30-59)$ & $7(6.8,7.0)$ \\
\hline Salicylic acid & - & - \\
\hline Syningic acid & $5(4.2-5.9)$ & - \\
\hline Protocatechuric acid & 88 & - \\
\hline Hydroxycinnamic acids & $162(62-334)$ & $130-154$ \\
\hline CIS/Trans-coutaric & $20(16-24)$ & 1.8 \\
\hline CIS/Trans-caftaric & $25(11-47)$ & $5(3,7)$ \\
\hline Caffeic acid ${ }^{\mathrm{b}}$ & $8.5(3-18)$ & 2.8 \\
\hline Coumaric acid ${ }^{b}$ & $12.6(7.5-22)$ & $I .5(I-2)$ \\
\hline Ferulic acid ${ }^{b}$ & 19 & - \\
\hline Stilbenes & $12.3(4-19)$ & $1.8(0.04-3.5)$ \\
\hline Trans-resveratrol & $1.0(0.1-2.3)$ & $0.22(0.003-2.0)$ \\
\hline Flavonoids & $750-1060$ & $25-30$ \\
\hline Flavonols & $98(10-203)$ & Trace \\
\hline Quercetin & $18.8(5-53)$ & 0 \\
\hline Myricetin & $16.2(2-45)$ & 0 \\
\hline Kamempferol & 18 & 0 \\
\hline Rutin & $6.8(0.5-10.8)$ & 0 \\
\hline Flavanoids & $168(48-440)$ & $15-30$ \\
\hline Catechin & $89(27-191)$ & $17.3(3-35)$ \\
\hline Epicatechin & $57.3(21.4-128)$ & $13.6(2,18.9,21)$ \\
\hline Procyanidins & I7I (29-333) & $7.1(5-10)$ \\
\hline Anthocyanins & $281(20-500)$ & 0 \\
\hline Delphinidin 3-monoglucoside ${ }^{c, d}$ & 22 & 0 \\
\hline Cyanidin 3-monoglucoside ${ }^{c, d}$ & $20(2.8,38)$ & 0 \\
\hline Petunidin 3-monoglucoside $e^{c, d}$ & 18 & 0 \\
\hline Peonidin 3-monoglucoside ${ }^{c, d}$ & 32 & 0 \\
\hline Malvidin 3-monoglucoside $e^{c, d}$ & $93(24-170)$ & 1 \\
\hline Total phenolic acids and polyphenols & $1200(900-2500)$ & $200(190-290)$ \\
\hline
\end{tabular}

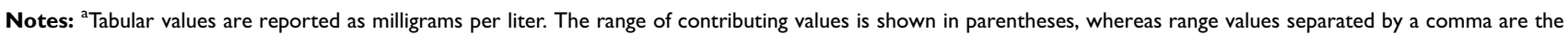
individual literature values contributing to an average. Values without a range are the sole value found. In some instances, only ranges were reported and are shown without a mean value. Dashes indicate no value found in literature. ${ }^{b}$ Also present as tartrate esters. ${ }^{\mathrm{C}}$ Also present as a diester with acetate. ${ }^{\mathrm{d}} \mathrm{Also}$ present as a diester with $\mathrm{p}-$ coumarate. Republished with permission of Annual Reviews, Inc, from German JB, Walzem RL. The health benefits of wine. Annual Reviews. 2000;20:56I-593. Copyright 2000; permission conveyed through Copyright Clearance Center, Inc.

other three, ${ }^{103}$ but only a limited number of grapes widely cultivated in California were considered in this study.

The grapes are pressed, and the juice sits for a while with the grape skins and stems still present when producing red wines. Because of this, the grape juice has a possibility to extract more of the Fvs and RST from the grape skins. Therefore, red wines have a higher concentration of antioxidants than whites. The antioxidant activity in 1 glass of red wine is equivalent to that found in 12 glasses of white wine, $500 \mathrm{~mL}$ of beer, 2 cups of tea, 7 glasses of orange juice, 20 glasses of apple juice, 3.5 glasses of black currant juice, 5 apples, $5(100 \mathrm{~g})$ portions of onion, or 5.5 portions of eggplant. ${ }^{18}$ Available studies show that red wine leads to healthier effects than white wine, and PPs are accountable for red wine properties. ${ }^{87}$ In controlled clinical trials, wine exhibited significantly higher anti-inflammatory and antioxidant effects than gin (ethanol without PPs). ${ }^{104}$ The antioxidant activity of red wine was found to correlate strongly with the total PPs content. ${ }^{105}$ Dealcoholized red wine decreased blood pressure more than gin but not more that red wine. ${ }^{64}$ The white sparkling wine (cava) have superior anti-inflammatory effects to the one of gin. ${ }^{106}$ Similarly, a randomized study showed that daily moderate consumption of Champagne wine may be linked with improved vascular 
performance. $^{107}$ In another controlled study, red wine decreased plasma factor VIIc and fibrinogen, and in increased PAI- 1 and t-PA. ${ }^{108}$ These properties of red wine, together with the Mediterranean diet, have beneficial effects on hemostatic CV risk factors. ${ }^{108}$ A systematic review highlighted that wine seems to provide higher cardiovascular protection than spirits because of their PPs content. ${ }^{109}$ Another study showed that lipoprotein(a) decreased after 10 days of red- but not white-wine intervention. ${ }^{110}$ Moderate red wine consumption is more protective on oxidative stress, inflammation, HDL cholesterol, Apo-A1, insulin sensitivity, cardiovascular and all-cause mortality than beer and liquors. $^{59}$

Procyanidins have been identified as the main vasoactive PPs in red wine. ${ }^{111}$ Furthermore, the antithrombotic effect of wine has been demonstrated in vivo ${ }^{112,113}$ and the higher intake of antioxidant-rich foods in general, and of PPs is linked with better cognitive performances in elderly subjects at high cardiovascular risk. ${ }^{114}$ Wine PPs decrease insulin resistance, ${ }^{55}$ decrease oxidative stress ${ }^{115}$ and increase antioxidant capacity116,117 that have been linked with decreased risk of diabetes, better glycemic control and reduced diabetes complications. ${ }^{1}$ These properties explain the protective effects of PPs on the colon and cardiovascular system, ${ }^{79}$ as well as in the prevention of neurodegenerative diseases such as cerebral ischemia, AD, Huntington's disease, Parkinson's disease, and may be potential therapeutic agents for inflammation, pain, tissue injury, diabetes, some types of cancer ${ }^{118}$ and oral hygiene. ${ }^{119}$ Effects of PPs, which may protect against stroke and coronary heart disease, include reduced LDL peroxidation, preserved HDLassociated paraoxonase, reduced macrophage atherogenicity, inhibition of formation of macrophage foam cells, ${ }^{120}$ reduced vasculature endothelin-1 synthesis, ${ }^{111}$ the stimulation of sirtuin activity and increased levels of endothelial nitric oxide synthase. $^{121,122}$ Proanthocyanidins, deriving from grape seeds, have significant protective properties against heart and vascular diseases. ${ }^{13}$

The actual beneficial effect of red wine has been popularly suggested to involve RST, but the statement that this polyphenol is the only one involved is not supported by scientific evidence. ${ }^{1}$ RST has anti-oxidizing, anti-aggregant and anti-inflammatory properties, blocks the proliferation of tumoral cells, triggers a process of self-destruction of tumoral and pre-tumoral cells ${ }^{13}$ and also has anti-viral properties inhibiting the rhinovirus, respiratory syncytial virus and fluvirus replication and reduces the synthesis of pro-inflammatory molecules like interleukin- 6 and $8^{123,124}$ It also has anti-
HIV activity, ${ }^{125}$ inhibits Epstein-Barr virus replication and its oncogenic pathway and lowers herpes simplex replication and other animal viruses. ${ }^{126}$ Clinical studies have shown that RST per-se does not substantially influence longevity, inflammation, cancer or cardiovascular disease in older adults. $^{127}$

Another study investigating the relationship between the concentration of RST metabolites and mortality concluded that RST does not explain the "French Paradox". ${ }^{28}$ This is sustained by the fact that RST content in the red wine is almost negligible. In addition, RST metabolism is very fast, and a few hours are enough to detect RST metabolites in urine.

The specific antioxidant properties of wine PPs may be particularly relevant in preventing dementia, ${ }^{129}$ and protecting from $\mathrm{AD} .{ }^{130}$ Moderate wine intake reduces the risk of dementia and stroke through 15 years while beer consumption has a negative effect. ${ }^{131,132}$ Furthermore, Klatsky et al showed that overall mortality was higher in those who imbibe beer or spirits than in wine drinkers. ${ }^{40}$ These findings suggest that there is something different explaining alcohol and wine effects; wine contains alcohol but has also something else inside that provides an additional benefit. Protection against AD might be due to PPs' anti-oxidative effect $^{130}$ on Acs present in the grape skin and immediately absorbed by the intestine and transferred to the brain, ${ }^{13}$ and to the stimulation of sirtuins activity by RST, linked with the regulation of the lifespan by extending cell survival. ${ }^{133}$

Red wine is a natural source of hydroxytyrosol and its assumption can promote endogenous hydroxytyrosol generation. ${ }^{134}$ Similarly, as moderate wine drinking does not elevate serum uric acid levels while liquor and, mainly, beer have a direct correlation with uricemia, ${ }^{7}$ PPs could have a role on this effect, too. The health effects related to grape and wine consumption may be linked with poorly understood phenolic acid metabolites. ${ }^{135}$ There is evidence that certain PPs, such as Acs, RST, catechins and Fos in wine provide several health benefits. Moreover, their metabolites, rather than PPs themselves, might be the real key players in cancer and cardiovascular protection. The health benefits associated with the Mediterranean diet, which combines a diet rich in fruits, vegetables and whole grains, with moderate wine consumption, suggests that PPs have synergistic effects with compounds available in other groups of foods. ${ }^{136}$ The precise nature and extent of the role played by PPs in human health is yet to be elucidated ${ }^{137}$ but the results of clinical trials clearly show PPs are behind beneficial effects of wine on health. 


\section{Other substances}

Extensive searches on medical databases do not report any evidence supporting that reducing sugars, net dry extract, total dry extract, non-reducing extract, relative density, color intensity and tone can influence wine healthiness in any manner.

\section{Quality of wine in general}

Wine quality is mainly determined by the grape and the winemaker. A study performed in Hungary highlighted that the toxic effects of alcohol can be reduced with an increased intake of quality wine and with decreased consumption linked with higher cost. Grapes characteristics are governed principally by the combination between climate and soil, affecting grape chemistry and subsequent wine quality. ${ }^{138}$ Even though some chemical tests can provide an indication on the quality of wine's aromas, ${ }^{139-142}$ several attempts to model quality evaluation have been proposed. ${ }^{143-145}$ To date, wine quality is mainly assessed by physicochemical and sensory (eg human expert evaluation) tests. ${ }^{144,146-151}$

Sensory preference is also very important to evaluate wine quality. Putting together this data in a model predicting perceived quality from chemical wine composition, higher alcohol concentration tends to result in a better wine (this seems true between 9-13\%). In addition, wine's volatile acidity has a negative influence since acetic acid is the key ingredient in vinegar. Furthermore, residual sugar concentrations are important in sweet wine where the equilibrium between the sweet taste and freshness is more appreciated. The most fascinating result is the elevated importance of sulphates, ranked second. ${ }^{145,152}$ Higher retro-nasal aroma release has been observed in wines having higher concentrations of PPs. ${ }^{153}$ These parameters are evaluated by several producers and governmental control bodies, thus routinely performed in good quality wines.

Several attempts to evaluate objectively the sensory quality of wines have been performed by different groups of wine testers and experts. Some wine tester organizations have developed various instruments to calculate a "quality score" to evaluate and, possibly, compare different wines. ${ }^{154,155}$ The same wine tastes differently when produced in different years as it belongs to the same grape(s) exposed to different environmental conditions through the production year. Comparing a sparkling wine with an old red one clearly makes no sense. Thus, each wine tastes better than another when considering the same genre (meaning one sparkling wine tastes better than another) but individual preference always predominates.
To appreciate the quality of a wine while testing it, some aspects should be considered: aspect, flavor, taste, general balance, elegance, age, and how to drink it with the right food. The basic tastes of wine on the palate are complemented by its aromatic characteristics, sensed by the olfactory system by way of the retro-nasal passage at the back of the mouth. When the taster inhales through the mouth and exhales through the nose, these aromas are conveyed to the olfactory bulb. This effect is affected by several factors. One is the light evaporation that happens when the wine is warmed by the mouth. Furthermore, wine is compressed and agitated by the chewing motion used by tasters, liberating smelling particles. Finally, saliva chemically modifies some substances in wine letting them odorous. Several associations perform professional courses to teach wine appreciation and evaluation. ${ }^{154-158}$ This is a very complex task that needs years of genuine application allowing only the most talented people to really distinguish a wine simply by tasting it. World wine tasting championships take place each year, where these capacities are highlighted and compared. Generally speaking, good quality wines are more associated with health. They are obtained by selected grapes from selected vineyards, through production systems that, although expensive and associated with a lower amount of high quality product, consent to reduce chemical manipulation of wine. In most countries worldwide, quality wines have to undergo strict controls by competent authorities before commercialization.

Furthermore, refined, ie good tasting wines are mostly enjoyed for their sensorial experience, rather than an alcoholrelated neurotropic effect. Therefore, the consumer of quality wines usually drinks slowly and moderately during meals and is well distant from those behaviors typical of alcohol addiction. The production of quality wine creates employment opportunities, improves the use of land and increases the incomes of producers and, indirectly, of local communities. The supply of quality wine can also contribute to a healthy lifestyle, promote social relations and reduce criminality related to alcohol's influence and adulteration. In general, the production and supply of good wine can have an overall beneficial impact on health ${ }^{138}$ and influences wine's salubrity.

\section{Discussion}

There exists a wide consensus that a moderate daily consumption of wine, especially while eating, has a good impact on health. The positive advantage of drinking wine has a "J" curve, ${ }^{159}$ as not drinking appears more risky than 1 (for women) or 2 (for men) glasses of wine 
per day, as well as higher daily consumption. Furthermore wine, as with any alcoholic beverage, can have a toxic effect when acute or chronic intake of high dosages is consumed. Alcohol could cause dependence and uncontrolled intake is a social problem in some countries. ${ }^{160}$

Among dietary components, wine is unmatched for the strong emotional elements that surround its consumption. In comparison with other alcoholic beverages, wine consumption is associated with healthier behavior, less risk factors for major illnesses and higher socioeconomic status. As epidemiological studies cannot analyze all possible confounding factors, the healthier status of consumers might influence the observed unique effects of wine. ${ }^{161}$ Even if red wine contains more PPs than white wine, there is no consensus on whether the type of wine drunk influences the benefits to longevity; some epidemiological studies highlighted an association with red wine, while others did not find any differences between red and white wine. Wine is a "living" product, whose chemical properties may vary through time according to place of production, grape varieties used, climatic factors, production technique and the producer's ability and storage. All these factors affect not only the organoleptic properties of a given wine, its tasting notes and its commercial success, but also its potential impact on health.

\section{Conclusion}

We have herein developed an algorithm taking into consideration all the evidence available to date on the substances contained in wine that might influence health (Figure 1). The Wine Index of Salubrity and Health (WISH) index has been determined based upon the correct dose to be introduced for each meal.

The debate as to whether the positive effect of red wine on longevity and health is only due to its content in ethanol or whether it has additional benefits linked with its nonalcoholic content remains open and therefore the algorithm might need to be modified according with the outcomes of new studies. Any future clinical trial that can provide clear evidence on the subject is anxiously awaited. To date we can affirm that moderate wine drinkers should not be discouraged and physicians can propagate the statement that moderate wine consumption may have beneficial effects. ${ }^{162}$

Consumers welcome more health-related information on alcoholic beverage packages. ${ }^{39}$ Campaigns on conscious drinking are already ongoing in several of the most advanced countries. Our hope is that, by introducing an index of salubrity on bottle labels and wine brochures, this scientific evidence can support physicians, authorities and people to make the right decisions for decreasing mortality and improving quality of life.

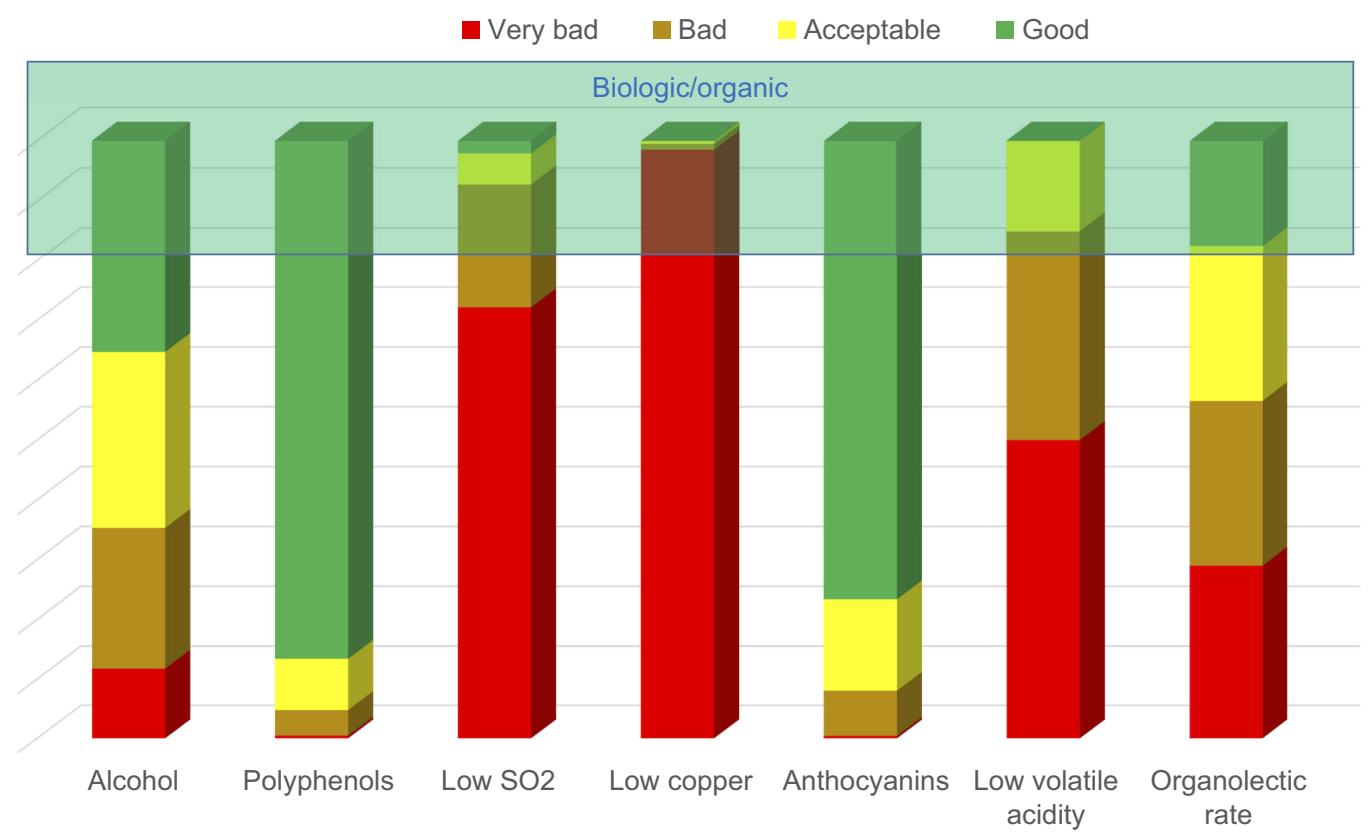

Figure I Factors influencing the Wine Index of Salubrity and Health (WISH). 


\section{Acknowledgments}

This article has been developed by authors without any support grant or sponsorship. The authors thank Roberta d'Emmanuele di Villa Bianca of the Department of Pharmacy, University of Naples, for her suggestions and continuous encouragement. We'll never thank enough Carla Benci, and Juliet Ippolito, professional medical writers, for their friendly editorial revision and feedback.

\section{Disclosure}

The authors report no conflicts of interest in regard to this work.

\section{References}

1. Robertson RP. Red wine and diabetes health: getting skin in the game. Diabetes. 2014;63(1):31-38. doi:10.2337/db13-1318

2. Robinson J. The Oxford Companion to Wine. Oxford Companion to Wine. 3rd. Vol. 1; 2006:840. doi:641.22 R22.

3. Mortensen EL, Jensen HH, Sanders SA, et al. Better psychological functioning and higher social status may largely explain the apparent health benefits of wine. Arch Intern Med. 2001;161(15):1844. doi:10.1001/archinte.161.15.1844

4. Stranges S, Notaro J, Freudenheim JL, et al. Alcohol drinking pattern and subjective health in a population-based study. Addiction. 2006;101 (9):1265-1276. doi:10.1111/j.1360-0443.2006.01517.x

5. Valencia-Martín JL, Galán I, Rodríguez-Artalejo F. Alcohol and selfrated health in a Mediterranean country: the role of average volume, drinking pattern, and alcohol dependence. Alcohol Clin Exp Res. 2009;33(2):240-246. doi:10.1111/j.1530-0277.2008.00826.x

6. Oksanen A, Kokkonen H. Consumption of wine with meals and subjective well-being: A finnish population-based study. Alcohol Alcohol. 2016;51(6):716-722. doi:10.1093/alcalc/agw016

7. Choi HK, Curhan G. Beer, liquor, and wine consumption and serum uric acid level: the Third National Health and Nutrition Examination Survey. Arthritis Rheum. 2004;51(6):1023-1029. doi:10.1002/art.20821

8. Kutlesa Z, Budimir Mrsic D. Wine and bone health: a review. J Bone Miner Metab. 2016;34(1):11-22. doi:10.1007/s00774-015-0660-8

9. Mondaini N, Cai T, Gontero P, et al. Regular moderate intake of red wine is linked to a better women's sexual health. J Sex Med. 2009;6 (10):2772-2777. doi:10.1111/j.1743-6109.2009.01393.x

10. Stockley CS, Hoj PB. Better wine for better health: fact or fiction? [Review]. Aust J Grape Wine Res. 2005;11(2):127-138. doi:10.1111/j.1755-0238.2005.tb00284.x

11. Boffetta P, Garfinkel L. Alcohol drinking and mortality among men enrolled in an American Cancer Society prospective study. Epidemiology. 1990;1(5):342-348.

12. Ancel Keys MK. Eat Well, Stay Well. NY: Doubleday; 1958.

13. Giacosa A, Barale R, Bavaresco L, et al. Cancer prevention in Europe: the Mediterranean diet as a protective choice. Eur J Cancer Prev. 2013;22(1):90-95. doi:10.1097/CEJ.0b013e328354d2d7

14. Urquiaga I, Guasch V, Marshall G, et al. Effect of Mediterranean and occidental diets, and red wine, on plasma fatty acids in humans. An intervention study. Biol Res. 2004;37(2):253-261. doi:10.4067/ S0716-97602004000200012

15. van Velden DP, Mansvelt EP, Fourie E, et al. The cardioprotective effect of wine on human blood chemistry. Ann N Y Acad Sci. 2002;957:337-340.
16. Estruch R, Martínez-González MA, Corella D, et al. Effects of a Mediterranean-style diet on cardiovascular risk factors a randomized trial. Ann Intern Med. 2006;145(1):1-11. 145/1/1 [pii].

17. Fitó M, Guxens M, Corella D, et al. Effect of a traditional Mediterranean diet on lipoprotein oxidation: a randomized controlled trial. Arch Intern Med. 2007;167(11):1195-1203. doi:10.1001/archinte.167.11.1195

18. German JB, Walzem RL. The health benefits of wine. Annual Reviews. 2000;20:561-593. doi:10.1146/annurev.nutr.20.1.561

19. Klatsky A, Armstrong M, Kipp H. Correlates of alcoholic beverage preference: traits of persons who choose wine, liquor or beer. $\mathrm{Br} J$ Addict. 1990;85(10):1279-1289. doi:10.1111/j.1360-0443.1990. tb01604.x

20. Ruf JC. Overview of epidemiological studies on wine, health and mortality. Drugs Exp Clin Res. 2003;29(5-6):173-179.

21. Renaud S, de Lorgeril M. Wine, alcohol, platelets, and the French paradox for coronary heart disease. Lancet. 1992;339(8808):15231526. doi:10.1016/0140-6736(92)91277-F

22. Koppes LLJ, Dekker JM, Hendriks HFJ, et al. Meta-analysis of the relationship between alcohol consumption and coronary heart disease and mortality in type 2 diabetic patients. Diabetologia. 2006;49(4):648-652. doi:10.1007/s00125-005-0127-x

23. Klarich DS, Brasser SM, Hong MY. Moderate alcohol consumption and colorectal cancer risk. Alcohol Clin Exp Res. 2015;39(8):12801291. doi:10.1111/acer. 12778

24. Aleixandre JL, Aleixandre-Tudó JL, Bolaños-Pizzaro M, et al. Mapping the scientific research on wine and health (2001-2011). J Agric Food Chem. 2013;61(49):11871-11880. doi:10.1021/ jf404394e

25. Walzem RL. Wine and health: state of proofs and research needs. Inflammopharmacology. 2008;16(6):265-271. doi:10.1007/s10787008-8027-6

26. Rimm EB, Giovannucci EL, Willett WC, et al. Prospective study of alcohol consumption and risk of coronary disease in men. Lancet. 1991;338(8765):464 468. doi:10.1016/0140-6736(91)90542-W

27. Mukamal KJ, Ascherio A, Mittleman MA, et al. Alcohol and risk for ischemic stroke in men: the role of drinking patterns and usual beverage. Ann Intern Med. 2005;142:1. doi:10.7326/0003-4819142-1-200501040-00007

28. Djoussé L, Gaziano JM. Alcohol consumption and heart failure: a systematic review. Curr Atheroscler Rep. 2008;10(2):117-120. doi:10.1007/s11883-008-0017-z

29. Renaud S, Lanzmann-Petithory D, Gueguen R, Conard P. Alcohol and mortality from all causes. Biol Res. 2004;37(2):183-187. doi:10.4067/s0716-97602004000200002

30. Holahan CJ, Schutte KK, Brennan PL, et al. Late-life alcohol consumption and 20-year mortality. Alcohol Clin Exp Res. 2010;34(11):1961-1971. doi:10.1111/j.1530-0277.2010.01286.x

31. Streppel MT, Ocke MC, Boshuizen HC, et al. Long-term wine consumption is related to cardiovascular mortality and life expectancy independently of moderate alcohol intake: the Zutphen study. J Epidemiol Community Heal. 2009;63(7):534-540. doi:10.1136/ jech.2008.082198

32. Okla M, Kang I, Kim DM, et al. Ellagic acid modulates lipid accumulation in primary human adipocytes and human hepatoma Huh7 cells via discrete mechanisms. J Nutr Biochem. 2015;26 (1):82-90. doi:10.1016/j.jnutbio.2014.09.010

33. Gea A, Beunza JJ, Estruch R, et al. Alcohol intake, wine consumption and the development of depression: the PREDIMED study. BMC Med. 2013;11(1):192. doi:10.1186/1741-7015-11-192

34. Letenneur L. Risk of dementia and alcohol and wine consumption: a review of recent results. Biol Res. 2004;37(2):189-193. doi:10.4067/S0716-97602004000200003

35. Caimi G, Carollo C, Lo Presti R. Wine and endothelial function. Drugs Exp Clin Res. 2003;29(5-6):235-242. 
36. Klatsky AL. Is abstinence from red wine hazardous to your health? Perm J. 2007;11(2):86-88. doi:10.7812/tpp/07-007

37. Ghislandi PC Farmacopea \& Vino. https://www.vinix.com/ myDocDetail.php?ID=2037\&lang=ita; October24, 2008. Accessed July 26, 2018.

38. Jesu G. La Nuova Tutela Dei Vini DOC E IGT. Rimini: Maggioli Editore; 2012.

39. Broholm K, Galluzzo L, Gandin C, et al. Good Practice Principles for Low Risk Drinking Guidelines. Montonen M, Mäkelä P; Scafato E. \& Gandin C. on behalf of Joint Action RARHA's Work Package 5 working group. National Institute for Health and Welfare (THL) www.thl.fi www.rarha.eu;HRB (Electronic Only). http://urn.fi/URN: ISBN:978-952-302-734-3. Accessed October 2016.

40. Klatsky AL, Friedman GD, Armstrong MA, et al. Wine, liquor, beer, and mortality. Am J Epidemiol. 2003;158(6):585-595. doi:10.1093/aje/kwg184

41. Rimm EB, Williams P, Fosher K, et al. Moderate alcohol intake and lower risk of coronary heart disease: meta-analysis of effects on lipids and haemostatic factors. Bmj. 1999;319(7224):1523-1528. doi:10.1136/bmj.319.7224.1523

42. Vogel RA. Vintners and vasodilators: are French red wines more cardioprotective? J Am Coll Cardiol. 2003;41(3):479-481. doi:10.1016/S0735-1097(02)02825-5

43. Bergmann MM, Rehm J, Klipstein-Grobusch K, et al. The association of pattern of lifetime alcohol use and cause of death in the European Prospective Investigation into Cancer and Nutrition (EPIC) study. Int J Epidemiol. 2013;42(6):1772-1790. doi:10.1093/ije/dyt154

44. Mukamal KJ, Conigrave KM, Mittleman MA, et al. Roles of drinking pattern and type of alchohol consumed in coronary heart disease in men. $N$ Engl J Med. 2003;348:109-118. doi:10.1056/ NEJMoa022095

45. Bell S, Daskalopoulou M, Rapsomaniki E, et al. Association between clinically recorded alcohol consumption and initial presentation of 12 cardiovascular diseases: population based cohort study using linked health records. Bmj. 2017:j909. doi:10.1136/bmj.j909.

46. Cosmi F, Di Giulio P, Masson S, et al. Regular wine consumption in chronic heart failure: impact on outcomes, quality of life, and circulating biomarkers. Circ Heart Fail. 2015;8(3):428-437. doi:10.1161/CIRCHEARTFAILURE.114.002091

47. Tresserra-Rimbau A, Medina-Remón A, Lamuela-Raventós RM, et al. Moderate red wine consumption is associated with a lower prevalence of the metabolic syndrome in the PREDIMED population. $\mathrm{Br} \quad J$ Nutr. 2015;113(Suppl):S121-S30. doi:10.1017/ S0007114514003262

48. Janssen I, Powell LH, Wildman RP. Moderate wine consumption inhibits the development of the metabolic syndrome: the Study of Women's Health Across the Nation (SWAN). J Wine Res. 2011;22 (2):113-117. doi:10.1080/09571264.2011.603217

49. Dragoni S, Gee J, Bennett R, et al. Red wine alcohol promotes quercetin absorption and directs its metabolism towards isorhamnetin and tamarixetin in rat intestine in vitro. $\mathrm{Br} J$ Pharmacol. 2006;147(7):765-771. doi:10.1038/sj.bjp.0706662

50. Serafini M, Maiani G, Ferro-Luzzi A. Effect of ethanol on red wine tannin-protein (BSA) interactions. J Agric Food Chem. 1997;45(1 $\mathrm{mL})$ :3148-3151. doi:10.1021/jf960864x

51. Natella F, Macone A, Ramberti A, et al. Red wine prevents the postprandial increase in plasma cholesterol oxidation products: a pilot study. Br J Nutr. 2011:1-6. doi:10.1017/S0007114510005544.

52. Addolorato G, Leggio L, Ojetti V, et al. Effects of short-term moderate alcohol administration on oxidative stress and nutritional status in healthy males. Appetite. 2008;50(1):50-56. doi:10.1016/j. appet.2007.05.008

53. Brien SE, Ronksley PE, Turner BJ, et al. Effect of alcohol consumption on biological markers associated with risk of coronary heart disease: systematic review and meta-analysis of interventional studies. BMJ. 2011;342:d636. doi:10.1136/bmj.d636
54. Estruch R, Sacanella E, Badia E, et al. Different effects of red wine and gin consumption on inflammatory biomarkers of atherosclerosis: a prospective randomized crossover trial: effects of wine on inflammatory markers. Atherosclerosis. 2004;175(1):117-123. doi:10.1016/j.atherosclerosis.2004.03.006

55. Chiva-Blanch G, Urpi-Sarda M, Ros E, et al. Effects of red wine polyphenols and alcohol on glucose metabolism and the lipid profile: a randomized clinical trial. Clin Nutr. 2013;32(2):200206. doi:10.1016/j.clnu.2012.08.022

56. Kohsaka S, Jin Z, Rundek T, et al. Alcohol consumption and atherosclerotic burden in the proximal thoracic aorta. Atherosclerosis. 2011;219(2):794-798. doi:10.1016/j.atherosclerosis.2011.07.129

57. Park H, Kim K. Association of alcohol consumption with lipid profile in hypertensive men. Alcohol Alcohol. 2012;47(3):282287. doi:10.1093/alcalc/ags019

58. Avellone G, Di Garbo V, Campisi D, et al. Effects of moderate Sicilian red wine consumption on inflammatory biomarkers of atherosclerosis. Eur J Clin Nutr. 2006;60(1):41-47. doi:10.1038/ sj.ejcn. 1602265

59. Chiva-Blanch G, Arranz S, Lamuela-Raventos RM, et al. Effects of wine, alcohol and polyphenols on cardiovascular disease risk factors: evidences from human studies. Alcohol Alcohol. 2013;48 (3):270-277. doi:10.1093/alcalc/agt007

60. Baliunas DO, Taylor BJ, Irving H, et al. Alcohol as a risk factor for type 2 diabetes: a systematic review and meta-analysis. Diabetes Care. 2009;32(11):2123-2132. doi:10.2337/dc09-0227

61. Okubo Y, Suwazono Y, Kobayashi E, et al. Alcohol consumption and blood pressure change: 5-year follow-up study of the association in normotensive workers. J Hum Hypertens. 2001;15(6):367372. doi:10.1038/sj.jhh.1001191

62. Taylor B, Irving HM, Baliunas D, et al. Alcohol and hypertension: gender differences in dose-response relationships determined through systematic review and meta-analysis: REVIEW. Addiction. 2009;104(12):1981-1990. doi:10.1111/j.1360-0443. 2009.02694.x

63. Xin X, He J, Frontini MG, et al. Effects of alcohol reduction on blood pressure: a meta-analysis of randomized controlled trials. Hypertension. 2001;38(5):1112-1117. doi:10.1161/hy1101.093424

64. Chiva-Blanch G, Urpi-Sarda M, Ros E, et al. Dealcoholized red wine decreases systolic and diastolic blood pressure and increases plasma nitric oxide: short communication. Circ Res. 2012;111 (8):1065-1068. doi:10.1161/CIRCRESAHA.112.275636

65. Frisoli TM, Schmieder RE, Grodzicki T, et al. Beyond salt: lifestyle modifications and blood pressure. Eur Heart J. 2011;32(24):30813087. doi:10.1093/eurheartj/ehr379

66. Stranges S, Wu T, Dorn JM, et al. Relationship of alcohol drinking pattern to risk of hypertension: A population-based study. Hypertension. 2004;44(6):813-819. doi:10.1161/01.HYP.000 0146537.03103.f2

67. Reynolds K, Lewis B, Nolen JDL, et al. Alcohol consumption and risk of stroke: a meta-analysis. Jama. 2003;289(5):579-588.

68. Costanzo S, Di Castelnuovo A, Donati MB, et al. Alcohol consumption and mortality in patients with cardiovascular disease. a meta-analysis. J Am Coll Cardiol. 2010;55(13):1339-1347. doi:10.1016/j.jacc.2010.01.006

69. Bond JC, Greenfield TK, Patterson DKW. Adjustments for drink size and ethanol content: new results from a self-report diary and transdermal sensor validation study. Alcohol Clin Exp Res. 2014;38 (12):3060-3067. doi:10.1111/acer.12589

70. Britton A, O'Neill D, Bell S. Underestimating the alcohol content of a glass of wine: the implications for estimates of mortality risk. Alcohol Alcohol. 2016;51(5):609-614. doi:10.1093/alcalc/agw027

71. Regueiro J, Vallverdú-Queralt A, Simal-Gándara J, et al. Urinary tartaric acid as a potential biomarker for the dietary assessment of moderate wine consumption: a randomised controlled trial. $\mathrm{Br} J$ Nutr. 2014;111(9):1680-1685. doi:10.1017/S0007114513004108 
72. Pérez-Mañá C, Farré M, Pujadas M, et al. Ethanol induces hydroxytyrosol formation in humans. Pharmacol Res. 2015;95-96:2733. doi:10.1016/j.phrs.2015.02.008

73. Schaffer S, Podstawa M, Visioli F, et al. Hydroxytyrosol-rich olive mill wastewater extract protects brain cells in vitro and ex vivo. $J$ Agric Food Chem. 2007;55(13):5043-5049. doi:10.1021/jf0703710

74. Fenech M, Stockley C, Aitken C. Moderate wine consumption protects against hydrogen peroxide-induced DNA damage. Mutagenesis. 1997;12(4):289-296. doi:10.1093/mutage/12.4.289

75. Visioli F, Galli C, Plasmati E. Olive phenol hydroxytyrosol prevents passive smoking-induced oxidative stress. Circulation. 2000;102(18):2169-2171. doi:10.1161/01.CIR.102.18.2169

76. Istituto Superiore di Sanità. Sperimentazione PASSI d'Argento (Progressi delle Aziende Sanitarie per la Salute in Italia): verso un sistema nazionale di sorveglianza della popolazione ultra64enne. A cura del Gruppo Tecnico di Coordinamento del Sistema di Sorveglianza PASSI d'Argento e Paola Luzi. ix, 211 p. Rapporti ISTISAN 13/9. 2013.

77. Conibear H. Social aspects and communication regarding alcohol and health via national drinking guidelines. J Wine Res. 2011;22 (2):187-193. doi:10.1080/09571264.2011.606014

78. Ecker RR, Klatsky AL. Doctor, should I have a drink? An algorithm for health professionals. Ann N Y Acad Sci. 2002;957:317320. doi:10.1111/j.1749-6632.2002.tb02932.x

79. Sicheri G. Un Po' Di Vino, Tanta Salute. Milano: Edizione; 2007

80. Trevisan M, Schisterman E, Mennotti A, et al. Drinking pattern and mortality: the Italian risk factor and life expectancy pooling project. Ann Epidemiol. 2001;11(5):312-319. doi:10.1016/S1047-2797(00) 00183-6

81. ISTITUTO SUPERIORE DI SANITÀ. Epidemiologia e monitoraggio alcol-correlato in Italia e nelle Regioni Valutazione dell'Osservatorio Nazionale Alcol-CNESPS sull'impatto del consumo di alcol ai fini dell'implementazione delle attività del Piano Nazionale Alcol e Salute Rapporto 2016 Emanuele Scafato, Claudia Gandin, Lucilla Di Pasquale, Lucia Galluzzo, Sonia Martire, Silvia Ghirini per il Gruppo di Lavoro CSDA (Centro Servizi Documentazione Alcol) Centro Nazionale di Epidemiologia, Sorveglianza e Promozione della Salute. Rapporti ISTISAN 16/4. ISSN: 2384-8936

82. Grønæk M, Jensen MK, Johansen D, et al. Intake of beer, wine and spirits and risk of heavy drinking and alcoholic cirrhosis. Biol Res. 2004;37(2):195-200. doi:10.4067/s0716-97602004000200004

83. Neeley E. Volatile acidity. http://waterhouse.ucdavis.edu/whats-inwine/volatile-acidity. Accessed July 26, 2018.

84. Mas A, Torija MJ, García-Parrilla MDC, Troncoso AM. Acetic acid bacteria and the production and quality of wine vinegar. Sci World J. 2014;2014. doi:10.1155/2014/394671.

85. EFSA Panel on Dietetic Products, Nutrition and Allergies (NDA). European Food Safety Authority (EFSA), Parma, Italy.Scientific Opinion on the evaluation of allergenic foods and food ingredientsfor labelling purposes. EFSA Journal.2014;12(11):3894. doi: $10.2903 /$ j.efsa. 2014.3894

86. Woolf S Sulfites in wine: friend or foe? Decanter. http://water house.ucdavis.edu/whats-in-wine/volatile-acidity. Accessed July 26, 2018

87. Pozo-Bayón MÁ, Monagas M, Bartolomé B, et al. Wine features related to safety and consumer health: an integrated perspective. Crit Rev Food Sci Nutr. 2012;52(1):31-54. doi:10.1080/ 10408398.2010.489398

88. Waterhouse AL. Sulfites. Waterhouse lab. http://waterhouse.ucda vis.edu/whats-in-wine/sulfites-in-wine. Accessed July 26, 2018.

89. UNION TCOTE. Council regulation (EC) No 834/2007 of 28 June 2007 on organic production and labelling of organic products and repealing Regulation (EEC) No 2092/91. Off $J$ Eur Union. 2007;189(1):1-23
90. Volschenk H, Van Vuuren HJJ. Malic acid in wine : origin, function and metabolism during vinification. S Afr J Enol Vitic. 2006;27 (2):123-136.

91. Tariba B. Metals in wine - Impact on wine quality and health outcomes. Biol Trace Elem Res. 2011;144(1-3):143-156. doi:10.1007/s12011-011-9052-7

92. Grillet JP, Adjémian A, Bernadac G, et al. Arsenic exposure in the wine growing industry in ten French departments. Int Arch Occup Environ Health. 2004;77(2):130-135. doi:10.1007/s00420-0030490-1

93. World Health Organization. Environmental health criteria 165: inorganic lead. Environ Heal Criteria. 1995;165:3-300.

94. World Health Organization. Environmental Health Criteria 134 Cadmium. IPCS International Program on Chemical Safety. Geneva: World Health Organization;1992. ISBN 9241571349.

95. WHO (World Health Organization). Copper. Environmental health criteria 200. In: IPCS-International Programme on Chemical Safety. Geneva: World Health Organization;1998.

96. Creasy GLC. Grape-derived wine flavonoids and stilbenes. In: Wine: A Scientific Exploration. London: Taylor and Francis;2003:199-227. ISBN 0415247349.

97. Paganga G, Miller N, Rice-Evans CA. The polyphenolic content of fruit and vegetables and their antioxidant activities. What does a serving constitute? Free Radic Res. 1999;30(2):153-162. doi:10.1080/10715769900300161

98. Pérez DD, Strobel P, Foncea R, et al. Wine, diet, antioxidant defenses, and oxidative damage. Ann N Y Acad Sci. 2002;957:136-145.

99. Khan NQ, Patel B, Kang SS, et al. Regulation of vascular endothelial function by red wine procyanidins: implications for cardiovascular health. Tetrahedron. 2015;71:3059-3065. doi:10.1016/j. tet.2014.10.078

100. Sacanella E, Vázquez-Agell M, Mena MP, et al. Down-regulation of adhesion molecules and other inflammatory biomarkers after moderate wine consumption in healthy women: A randomized trial. Am J Clin Nutr. 2007; 86(5):1463-1469. 86/5/1463 [pii]. doi:10.1093/ajen/86.5.1463

101. Corder R, Douthwaite JA, Lees DM, et al. Endothelin-1 synthesis reduced by red wine. Nature. 2001;414(6866):863-864. doi:10.1038/ 414863a

102. Leikert JF. Red wine polyphenols enhance endothelial nitric oxide synthase expression and subsequent nitric oxide release from endothelial cells. Circulation. 2002;106(13):1614-1617. doi:10.1161/01.CIR.0000034445.31543.43

103. Wine and Health. Metal imagination. https://www.metalimagination com/blogs/wine/51568452-wine-and-health. Accessed July 26, 2018

104. Estruch R, Sacanella E, Mota F, et al. Moderate consumption of red wine, but not gin, decreases erythrocyte superoxide dismutase activity: a randomised cross-over trial. Nutr Metab Cardiovasc Dis. 2011;21(1):46-53. doi:10.1016/j.numecd.2009.07.006

105. Xiang L, Xiao L, Wang Y, et al. Health benefits of wine: don't expect resveratrol too much. Food Chem. 2014;156:258-263. doi:10.1016/j.foodchem.2014.01.006

106. Vázquez-Agell M, Sacanella E, Tobias E, et al. Inflammatory markers of atherosclerosis are decreased after moderate consumption of cava (sparkling wine) in men with low cardiovascular risk. $J$ Nutr. 2007; 137(10):2279-2284. 137/10/2279 [pii]. doi:10.1093/jn/ 137.10.2279

107. Vauzour D, Houseman EJ, George TW, et al. Moderate champagne consumption promotes an acute improvement in acute endothelialindependent vascular function in healthy human volunteers. $\mathrm{Br} J$ Nutr. 2009:1. doi:10.1017/S0007114509992959.

108. Mezzano D. Distinctive effects of red wine and diet on haemostatic cardiovascular risk factors. Biol Res. 2004;37(2):217-224. doi:10.4067/s0716-97602004000200007 
109. Haseeb S, Alexander B. Wine and cardiovascular health: a comprehensive review. Circulation. 2017;136(15):1434-1448. doi:10.1161/CIRCULATIONAHA.117.030387

110. Sharpe PC, McGrath LT, McClean E, et al. Effect of red wine consumption on lipoprotein (a) and other risk factors for atherosclerosis. Qjm. 1995;88(2):101-108.

111. Corder R, Mullen W, Khan NQ, et al. Oenology: red wine procyanidins and vascular health. Nature. 2006;444(7119):566. doi:10.1038/444566a

112. Mansvelt EP, van Velden DP, Fourie E, et al. The in vivo antithrombotic effect of wine consumption on human blood platelets and hemostatic factors. Ann N Y Acad Sci. 2002;957:329-332. doi:10.1111/j.1749-6632.2002.tb02935.x

113. Ruf JC. Alcohol, wine and platelet function. Biol Res. 2004;37 (2):209-215. doi:10.4067/s0716-97602004000200006

114. Valls-Pedret C, Lamuela-Raventós RM, Medina-Remón A, et al. Polyphenol-rich foods in the mediterranean diet are associated with better cognitive function in elderly subjects at high cardiovascular risk. $J$ Alzheimer's Dis. 2012;29(4):773-782. doi:10.3233/JAD-2012111799

115. Nakamura T, Fujiwara N, Sugaya T, et al. Effect of red wine on urinary protein, 8-hydroxydeoxyguanosine, and liver-type fatty acid-binding protein excretion in patients with diabetic nephropathy. Metabolism. 2009;58(8):1185-1190. doi:10.1016/j.metabol.2009.03.019

116. Alberti-Fidanza A, Burini G, Antonelli G, et al. Acute effects of lyophilised red wine on total antioxidant capacity in healthy volunteers. Diabetes Nutr Metab Clin Exp. 2003;16(1):65-71.

117. Noguer MA, Cerezo AB, Donoso Navarro E, et al. Intake of alcohol-free red wine modulates antioxidant enzyme activities in a human intervention study. Pharmacol Res. 2012;65(6):609-614. doi:10.1016/j.phrs.2012.03.003

118. Rege SD, Geetha T, Griffin GD, et al. Neuroprotective effects of resveratrol in Alzheimer disease pathology. Front Aging Neurosci. 2014;6:(AUG):1-27. doi:10.3389/fnagi.2014.00218

119. Cueva C, Mingo S, Muñoz-González I, et al. Antibacterial activity of wine phenolic compounds and oenological extracts against potential respiratory pathogens. Lett Appl Microbiol. 2012;54 (6):557-563. doi:10.1111/j.1472-765X.2012.03248.x

120. Aviram M, Fuhrman B. Wine flavonoids protect against LDL oxidation and atherosclerosis. Ann N Y Acad Sci. 2002;957:146161. doi:10.1111/j.1749-6632.2002.tb02913.x

121. Zheng W, Zhang H, Jin Y, et al. Small molecule activators of sirtuins extend Saccharomyces cerevisiae lifespan. Nature. 2014;19(3):191-196. doi:10.1038/nature01965.1

122. Howitz KT, Bitterman KJ, Cohen HY, et al. Small molecule activators of sirtuins extend Saccharomyces cerevisiae lifespan. Nature. 2003;425(6954):191-196. doi:10.1038/nature01960

123. Mastromarino P, Capobianco D, Cannata F, et al. Resveratrol inhibits rhinovirus replication and expression of inflammatory mediators in nasal epithelia. Antiviral Res. 2015;123:15-21. doi:10.1016/ j.antiviral.2015.08.010

124. Xie XH, Zang N, Li SM, et al. Resveratrol inhibits respiratory syncytial virus-induced IL-6 production, decreases viral replication, and downregulates TRIF expression in airway epithelial cells. Inflammation. 2012;35(4):1-10. doi:10.1007/s10753-012-9452-7

125. Clouser CL, Chauhan J, Bess MA, et al. Anti-HIV-1 activity of resveratrol derivatives and synergistic inhibition of HIV-1 by the combination of resveratrol and decitabine. Bioorg Med Chem Lett. 2012;22(21):6642-6646. doi:10.1016/j.bmcl.2012.08.108

126. Abba Y, Hassim H, Hamzah H, et al. Antiviral activity of resveratrol against human and animal viruses. Adv Virol. 2015;2015. doi:10.1155/2015/184241

127. Semba RD, Ferrucci L, Bartali B, et al. Resveratrol levels and allcause mortality in older community-dwelling adults. JAMA Intern Med. 2014;174(7):1077. doi:10.1001/jamainternmed.2014.1582
128. Tomé-Carneiro J, Larrosa M, González-Sarrías A, et al. Resveratrol and clinical trials: the crossroad from in vitro studies to human evidence. Curr Pharm Des. 2013;19(34):6064-6093. doi:10.2174/ 13816128113199990407

129. Orgogozo JM, Dartigues JF, Lafont S, et al. Wine consumption and dementia in the elderly: a prospective community study in the Bordeaux area. Rev Neurol (Paris). 1997;153(3):185-192. MDOIRN-05-1997-153-3-0035-3787-101019-ART58 [pii].

130. Pinder RM, Sandler M. Alcohol, wine and mental health: focus on dementia and stroke. J Psychopharmacol. 2004;18(4):449-456. doi: $10.1177 / 0269881104047272$

131. Truelsen T, Thudium D, Grønbaek M. Amount and type of alcohol and risk of dementia: the Copenhagen city heart study. Neurology. 2002;59 (9):1313-1319. doi:10.1212/01.WNL.0000031421.50369.E7

132. Truelsen T, Gronb KM, Schnohr P, et al. Intake of beer, wine, and spirits and risk of stroke : the Copenhagen City heart study. Stroke. 1998;29(12):2467-2472. doi:10.1161/01.STR.29.12.2467

133. Goldberg DMSGJ. Resveratrol: biochemistry, cell biology and the potential role in disease prevention. In: eds Merton Sandler, Roger Pinder. Wine: A Scientific Exploration. London: Taylor \& Francis; 2003:160-198.

134. De La Torre R, Covas MI, Pujadas MA, et al. Is dopamine behind the health benefits of red wine? Eur J Nutr. 2006;45(5):307-310. doi:10.1007/s00394-006-0596-9

135. Forester SC, Waterhouse AL. Metabolites are key to understanding health effects of wine polyphenolics. $J$ Nutr. 2009;139(9):1824S1831S. doi:10.3945/jn.109.107664

136. Arranz S, Chiva-Blanch G, Valderas-Martínez P, et al. Wine, beer, alcohol and polyphenols on cardiovascular disease and cancer. Nutrients. 2012;4(7):759-781. doi:10.3390/nu4070759

137. Visioli F, de la Lastra CA, Andres-Lacueva C, et al. Polyphenols and human health: A prospectus. Crit Rev Food Sci Nutr. 2011;51 (6):524-546. doi:10.1080/10408391003698677

138. Adam B, Molnar A, Bardos $\mathrm{H}$, et al. Health impact assessment of quality wine production in Hungary. Health Promot Int. 2009;24 (4):383-393. doi:10.1093/heapro/dap024

139. Ferreira V, Juan FS, Escudero A, et al. Modeling quality of premium spanish red wines from gas chromatography- olfactometry data. J Agric Food Chem. 2009;57(16):7490-7498. doi:10.1021/ jf9006483

140. Ferreira V, Sáenz-Navajas MP, Campo E, et al. Sensory interactions between six common aroma vectors explain four main red wine aroma nuances. Food Chem. 2016;199:447-456. doi:10.1016/j. foodchem.2015.12.048

141. Muñoz-González C, Rodríguez-Bencomo JJ, Moreno-Arribas MV, et al. Beyond the characterization of wine aroma compounds: LOOKING for analytical approaches in trying to understand aroma perception during wine consumption. Anal Bioanal Chem. 2011;401(5):1501-1516. doi:10.1007/s00216-011-5078-0

142. Sáenz-Navajas MP, Alegre Y, de-la-Fuente A, et al. Rapid sensorydirected methodology for the selection of high-quality aroma wines. $J$ Sci Food Agric. 2016;96:4250-4262. doi:10.1002/jsfa.7636

143. Lemionet A, Liu Y, Zhou Z Predicting quality of wine based on chemical attributes. http://cs229.stanford.edu/proj2015/245_report. pdf. Accessed 26 Jul 2018

144. Hopfer H, Nelson J, Ebeler SE, et al. Correlating wine quality indicators to chemical and sensory measurements. Molecules. 2015;20(5):8453-8483. doi:10.3390/molecules20058453

145. Horák M Prediction of wine quality from physicochemical properties; 2010. http://www.buben.piranhacz.cz/wp-content/uploads/ PredictionWineQuality_mhorak_VD.pdf. Accessed July 26, 2018.

146. Sáenz-Navajas MP, Campo E, Avizcuri JM, et al. Contribution of nonvolatile and aroma fractions to in-mouth sensory properties of red wines: wine reconstitution strategies and sensory sorting task. Anal Chim Acta. 2012;732:64-72. doi:10.1016/j.aca.2011.12.042 
147. Sáenz-Navajas MP, Campo E, Culleré L, et al. Effects of the nonvolatile matrix on the aroma perception of wine. J Agric Food Chem. 2010;58(9):5574-5585. doi:10.1021/jf904377p

148. Sáenz-Navajas MP, Ferreira V, Dizy M, et al. Characterization of taste-active fractions in red wine combining HPLC fractionation, sensory analysis and ultra performance liquid chromatography coupled with mass spectrometry detection. Anal Chim Acta. 2010;673(2):151-159. doi:10.1016/j.aca.2010.05.038

149. Sáenz-Navajas MP, Tao YS, Dizy M, et al. Relationship between nonvolatile composition and sensory properties of premium Spanish red wines and their correlation to quality perception. J Agric Food Chem. 2010;58(23):12407-12416. doi:10.1021/jf102546f

150. Schwarz R. Predicting wine quality from Terrain characteristics by regression trees. In: Dossiers, 10ème Colloque Européen De Géographie Théorique Et Quantitative. document 35; 1997. https://jour nals.openedition.org/cybergeo/361 . Accessed 6-11 septembre 1997.

151. Villamor RR, Ross CF. Wine matrix compounds affect perception of wine aromas. Annu Rev Food Sci Technol. 2013;4(1):1-20. doi:10.1146/annurev-food-030212-182707

152. Alekseeva D Red and white wine quality. RPubs. https://rpubs.com/ Daria/57835. Accessed July 26, 2018

153. Muñoz-González C, Martín-Álvarez PJ, Moreno-Arribas MV, et al. Impact of the nonvolatile wine matrix composition on the in vivo aroma release from wines. J Agric Food Chem. 2014;62(1):66-73. doi:10.1021/jf405550y
154. Carosso M Associazione Italiana Sommelier. https://www.aisita lia.it/area-formazione.aspx\#.W1nJ8dL-jIU. Accessed July 26, 2018

155. Faure-Brac P Association de la Sommellerie Française. https:// www.sommelier-france.org/. Accessed July 26, 2018

156. Rosberg A Association de la Sommellerie Internationale (A.S.I.). https:// www.sommellerie-internationale.com/. Accessed July 26, 2018.

157. The North American Sommelier Association. https:/www.nasom melier.com/. Accessed July 26, 2018.

158. Harris I Wine \& spirit education trust. https://www.wsetglobal.com/ about-us/. Accessed Jul,26, 2018.

159. Shaper AG, Wannamethee G, Walker M. Alcohol and mortality in British men: explaining the U-shaped curve. Lancet. 1988;332 (8623):1267-1273. doi:10.1016/S0140-6736(88)92890-5

160. Powrie I, O’Neill B, Merrick J, et al. Dealing with a social externality - alcohol and health. J Wine Res. 2014;25(2):105-126. doi:10.1080/09571264.2014.888647

161. Trent Preszler TMS. Factors affecting wine purchase decisions and presence of New York wines in upscale New York city restaurants. J Food Distrib Res. 2009;40:3.

162. Artero A, Artero A, Tarín JJ, et al. The impact of moderate wine consumption on health. Maturitas. 2015;80(1):3-13. doi:10.1016/j. maturitas.2014.09.007
International Journal of Wine Research

\section{Publish your work in this journal}

The International Journal of Wine Research is an international, peerreviewed open-access journal that focuses on all scientific aspects of wine, including: vine growing; wine elaboration; human interaction with wine; health aspects of wine. The journal provides an open access platform for the reporting of evidence based studies on these topics. The manuscript management system is completely online and includes a very quick and fair peer-review system, which is all easy to use. Visit http://www.dovepress.com/testimonials.php to read real quotes from published authors. 